\title{
Differences in Religious Socialisation across Generations Ján Mišovič
}

\section{Introduction}

The issue of religious socialisation is at the centre of the attention of many foreign authors. Their approaches, though, completely differ from contentual and methodological points of view. Some pay attention to the progress of socialisation within a particular society ${ }^{1}$ or focus on the process of adopting religions in different countries. ${ }^{2}$ Some notice the main socialisation factors associated with the influence of parents, ${ }^{3}$ while others approach complexly to circumstances explaining religious socialisation. ${ }^{4}$ In their analysis, they use (in addition to domestic research data) information about national units obtained from the International Social Survey Programme (ISSP) 2008: Religion III.

The topic of religious socialisation is also beginning to attract attention within Czech professional discourse $\mathrm{s}^{5}$, and the focus is on intergenerational and intragenerational transmission of religious beliefs in the Czech Republic and in surrounding countries.

The presented article builds on the approaches that characterise the forms of religiosity and non -religiosity of Czech society and focuses on the circumstances of religious socialisation in the Czech Republic. It deals with the degree of the intergenerational transmission of religious ideas. The aim is to assess the form of religious worldview within the Czech population and the trends connected with it and to find answers to the research question, i.e., what the role is of parental religious socialisation in the adoption of religious faith. During the interpretation of our findings, the results of a representative survey of Czech population (realised between December 2015 and January 2016) were used.

1 Cf., for example, Alasdair CROCKETT - David VOAS, Generations of Decline: Religious Change in $20^{\text {th }}$ Century Britain, Journal of the Scientific Study of Religion 4/2006, pp. 567-584.

2 Cf., for example, Tim MÜLLER - Peter SCHMIDT - Nan Dirk DE GRAFF, Which Societies Provide a Strong Religious Socialisation Context? Explanations Beyond the Effects of National Religiosity, Journal of the Scientific Study of Religion 4/2014, pp. 739-759.

3 Cf., for example, Richard PETTS, Paternal Religiosity and Youth Religiosity: Variations by Family Structure, Sociology of Religion 1/2015, pp. 95-120.

4 Cf., for example, Paul VERMEER - Jacques JANSEEN - Joep DE HART, Religious Socialisation and Chuch Attendance in the Netherlands from 1997 to 2007: a Panel Study, Social Compass 3/2011, pp. 371-392.

5 Cf., for example, Antonín PALEČEK - Roman VIDO, Náboženské vyznání v České republice z perspektivy inter- a intragenerační transmise, Naše společnost 2/2013, pp. 24-35; Antonín PALEČEK, Sekularizace z pohledu inter- a intragenerační transmise: ČR ve srovnání postkomunistických zemí střední Evropy, Naše společnost 2/2015, pp. 13-26. 


\section{The Theoretical Approaches to Religious Socialisation}

The starting point for the application of the socialisation processes (in the area of religion in the Czech Republic) is the idea that 'Czechs are far less non-religious than they would seem at first sight.' ${ }^{6}$ Most Czechs do not belong to any churches, do not attend religious services, and do not trust religious organisations. On the other hand, however, they are familiar with belief in so called supernatural power, magic. ${ }^{7}$ We rely on the theory of secularisation, which is based on reducing the importance of religion in society. It is characterised by structural differentiation, rationalisation, pluralism, and the loss of the dominant integration function of religion. In other words, by changing the way in which religion operates and by changing the place of religion in society. ${ }^{8}$

The definition of socialisation itself (which can be characterised as a process through which the same or similar values, norms, ideas, practices, beliefs, practical steps are passed from one generation to the next in order to enable the incoming members to participate in the ordinary life of society) is the basis for understanding its religious form. Socialisation in its broadest sense means integrating individuals into an existing social structure, while transmission and internalisation are the core of this process. ${ }^{9}$

Berger and Luckmann were dealing with the most general circumstances of socialisation when they characterised three intermediary parts contributing to its realisation. Significant others, usually parents, are the first agents who mediate social reality to the child/children, lead them towards the adoption of values, roles, norms, and present the world in a comprehensible form. A child later comes into contact with other children, peers, the wider family, and his or her surroundings, and expands his or her understanding of social reality. Such knowledge is essential for the child. $\mathrm{He}$ or she realises that the meanings important to his or her parents are considered equally important for other members of society. The impact of the wider surroundings represents the influence of less important others for the child. Both authors combine the functioning of these factors (in the process of internalisation) with a factor that allows the continuation of identification with the general others, i.e., with society. These socialisation circumstances are crucial because they involve the internalisation of society, respectively the social structure. 'Not only the content of socialisation but also the degree of its success is determined by socio-structural conditions and has socio-structural consequences.' ${ }^{10}$

Some of the authors leave aside the wider understanding of socialisation and focus especially on the role of parents and the family in the process of religious socialisation, ${ }^{11}$ that is, on the importance of the religious homogeneity of both parents. ${ }^{12}$

German experts remain in a more general context and perceive socialisation as a complex process, taking place in the background of four connected areas. ${ }^{13}$ Personality with its dispositions is the starting point of the whole process, which immediately initiates individual interactions.

Cf. Dušan LUŽNÝ - Zdeněk R. NEŠPOR et al., Náboženství v menšině. Praha: Malvern, 2008, p. 9.

Ibid., p. 25.

8 Cf. (C) Dušan LUŽNÝ, Sociologické teorie náboženství - potenciál průniků? (on-line), available at: http://css2017.ff.cz./prispevky/pdf, cited $24^{\text {th }}$ May 2017.

9 Cf., for example, VERMEER - JANSEEN - DE HART, Religious Socialisation..., pp. 371-392.

10 Cf., for example, Peter L. BERGER - Thomas LUCKMANN, Sociálni konstrukce reality, Brno: CDK. 1999.

11 Cf., for example, Christian SMITH - Melinda DENTON, Soul Searching. The Religious and Spiritual Lives of American Teenagers, New York: Oxford University Press, 2005; PETTS, Paternal Religiosity..., pp. 95-120.

12 Cf., for example, David HUTSEBAUT, Een zekere onzekerheid. Jongeren en geloof. Amersfoort: Acco, 1995, In: VERMEER - JANSEEN - DE HART, Religious Socialisation..., pp. 371-392.

13 Cf., for example, Klaus Jürgen TILLMANN, Socialisationstheorien. Eine Einführung in den Zusammenhang von Gesellshaft, Institution und Subjektwerdung, Reinbek bei Hamburg: Rowohlt, 2007. 
Socialisation is taking place continuously through personal contacts, direct communication face to face with other individuals, parents, in a specific family environment. These interactions with increasing age often take place in specific social institutions such as kindergarten, school, free time activities groups, peer groups, ecclesial community, etc., and constitute the third area of socialisation. Religious orientation is not formed only by the mind and behaviour of parents, but also by the environment in which people live, their friends, peer informal groups, teachers, and life counterparts. ${ }^{14}$ Society itself as a whole, which also influences the process of socialisation through its specific economic, political, social and cultural structures, is considered to be the fourth area. The interconnection between the four spheres is hierarchical in nature, which means that micro -level relations (respectively in the first two areas, individual and group) are influenced by the macro-level (created by institutions and society). The weakening of a traditional religious education of a child by social and cultural development at the macro level is one of the expressions of these links ${ }^{15}$ and this is manifested, for example, by an expanding individualisation, by a form of moral individualism as a result of the decreasing importance of traditional authority, ${ }^{16}$ or by identification with the process of rationalisation manifested by an increasing level of education and the use of urbanisation. ${ }^{17}$ The reluctance of people to participate in religious life is explained by the functioning of these factors. ${ }^{18}$ Coleman claims that rapid economic and social changes over the last few decades have led to differences in young people's thinking and understanding (compared to their parents) in areas such as work, family, gender issues, and sex, ${ }^{19}$ and this also applies to the subject of religion. ${ }^{20}$ The scope of mass culture and the intensity of its influence (unimaginable several decades ago) also supports the idea of a less significant impact of religion on the young generation compared to their parents. This may lead to tensions between the two generational groups in a religious environment. ${ }^{21}$

In connection with the decline in religiosity, both the role of age groups and time periods are considered. Evidence suggests that belonging to an age group appears to be more important than the action of specific events or circumstances at different times. ${ }^{22}$ As a result, more religiously oriented generations are replaced by younger, less religiously influenced groups. Both beliefs and religious affiliation (believing and belonging) are decreasing to the same extent, which is completely contrary to the arguments of Davie ${ }^{23}$ and others. ${ }^{24}$

Many studies of religious socialisation carried out in countries with different religiosity and religious backgrounds conclude that the influence of the socialising efforts of parents is diminishing and competing with other socialising factors, beginning with the environment outside one's family and ending with economic, social, and cultural changes. The current result of religious so-

14 Cf., for example, Jonathan KELLEY, National Context, Parental Socialisation, and Religious Belief in 38 Nations as of 2008: The End of National Exceptionalism?, Polish Sociological Review 3/2015, pp. 295-314.

15 Cf., for example, VERMEER - JANSEEN - DE HART, Religious Socialisation..., pp. 371-392.

16 Cf., for example, Dick HOUTMAN - Peter MANCINI, Why Do Churches Become Empty, While New Age Grows? Secularization and Religious Change in Netherlands, Journal for the Scientific Study of Religion 3/2002, pp. 455-473.

17 Cf., for example, Manfred TE GROTENHUIS - Peer SCHEEPERS, Churches in Dutch: Causes of Religious Disaffiliation in The Netherlands, 1933-1955?, Journal for the Scientific Study of Religion 4/2001, pp. 591-606.

18 Cf., for example, VERMEER - JANSEEN - DE HART. Religious Socialisation..., pp. 371-392.

19 Cf., for example, John COLEMAN, Young people in Britain at the beginning of a new century, Children and Society 4/2000, pp. $230-242$.

20 Cf., for example, Jan HORWATH - Janet LEES - Peter SIDEBOTHAM, The influence of religion on adolescent family life in England: an explanatory study of the views of young people and parents, Social Compass 2/2012. pp. 257-275.

21 Cf., for example, Ingrid STORM - David VOAS, The Intergenerational Transmission of Religious Service Attendence, Nordic Journal of Religion and Society 2/2012, pp. 131-150.

22 Cf., for example, CROCKETT - VOAS, Generations of Decline..., pp. 567-584.

23 Cf., for example, Grace DAVIE, New Approaches in the Sociology of Religion: A Western Perspective, Social Compass. 1/2004, pp. 73-84.

24 Cf., for example, CROCKETT - VOAS, Generations of Decline..., pp. 567-584. 
cialisation in the Czech Republic and the development of the situation in this direction will be indicated in further parts of this article.

\section{Methodology and Data}

The Czech authors, similar to some foreign ones, used international data from 2008 when analysing religious socialisation. Our approach was different. We used the data from a representative survey of the Czech population aged 15 years and older, ${ }^{25}$ (carried out by the Social Sciences Club, entitled The Influence of the Scope of Human Values and One's Worldview on Decisionmaking). There were 522 respondents included in the survey. Eighty interviewers from the Social Science Club's trained network conducted data collection between December 2015 and January 2016, based on quota selection and standardised interviews. The determiners for respondents were gender, age, education, the size of place of residence, and region. One of the topic areas focused on social and political theses related to the worldview of the respondents and their everyday life issues. This conceptualised content enabled (through the following variables) to also analyse religious feelings and thoughts, and circumstances of religious socialisation. As an indicator of religious belief, we considered the answer to the question: 'How important is faith in God to you? Very important, partly important, unimportant. The degree of religiosity was captured through consent or disagreement with the statement: 'Religion is the salvation of mankind. I agree totally; I agree partly; I disagree; I do not know' presented on the piece of paper. Another statement: 'I believe in supernatural powers. Yes, always; yes, sometimes; No, I do not' mapped the alternative religiosity of the respondents. The operationalised variable, referring to the concept of the essence of the world, was formulated as follows: 'You believe that the world has a materialistic nature, is governed by natural laws, or has a spiritual essence, is controlled by God or other supernatural powers, or you do not know.

Two separate queries followed the degree of religious orientation of the father and mother of the questioned participants in the following wording: 'Is it possible to say that your mother (father) has been or is a believer? Yes; partly; no. Comparing the answers to the last two questions within the basic age groups (i.e., the younger generation, the younger middle generation, the older generation and the oldest generation), is the basis for assessing the socialisation of religious ideas in a similar way to other authors. ${ }^{26}$ Faith in God in the questioned ones and the beliefs of both parents were surveyed nationwide also in 1991. It was a piece of research for the Czechoslovak Bible Society, sponsored by the World Bible Society and carried out in March 1991 at IVVM Prague. A group of citizens of the Czech Republic aged 15 and older, out of a number of 1961 respondents, was chosen by the method of quota selection with controlled characteristics (gender, age, size of place of residence, region, and economic activity). The selection for the current research was conducted in the same way and with the same controlled characters, except for economic activity, which was replaced by education.

The evaluation of individual aspects of religion and the degree of religious orientation of parents have been connected with the influence of subjective circumstances. The results of data comparisons between 1991 and 2016 (between age groups) were considered to be the consequence of objective circumstances. Cases where at least one of the parents was considered to be partially

25 In the research, a quota selection was used for the design of a representative set. It was done in the same way as for CVVM continuous research, Median research and for other CT (Czech Television) agencies, or the exit polls for CT.

26 Cf., for example, CROCKETT - VOAS, Generations of Decline..., pp. 567-584; Joel ROBBINS, How Do Religions End? Theorizing Religious Traditions from the Point of View of How They Disappear, Cambridge Anthropology 2/2014, pp. 2-15. 
believing and the respondent recognised belief in God as at least partly as important were considered to be a religious transfer. The reproduction of unbelief was observed in a group with both unbelieving parents following the lack of faith in God in regard to the respondent's attitude. The state was reflected as a deconversion if (at least) one of the parents was at least partially considered a believer and (at the same time) belief in God was not important to the respondent him/herself. The situation in which the respondent considered belief in God to be very or partly important while both parents were unbelievers we call conversion. It is certainly necessary to draw attention to the limits of the study. The first is that the six variables indicate religious worldview and allow a partial, indicative analysis of each age group. Another limiting factor is the size of the representative set. Yet, the tendencies given by us may be worthwhile in their next possible verification. ${ }^{27}$ The topic of religion and non-religion is presented in the following section.

\section{The Extent of Religious and Non-Religious Worldviews}

One of the aims of the study is to characterise the current expansion of the religious worldview in the Czech Republic and, in connection with this, to show the circumstances of religious socialisation, and the degree of generational transfer of religious and non-religious ideas and views. The interpretation of the block of questions indicating religiosity within the population of the Czech Republic and individual age groups seems to us to be the most effective. First, we introduce the layout of each aspect of religious orientation.

Table 1: Answers given by the Czech population and basic age groups about their religious orientation (in \%)

\begin{tabular}{|c|c|c|c|c|c|c|}
\hline & & ČR & $15-29 y r s$ & $\begin{array}{l}30-44 \\
\text { yrs }\end{array}$ & $\begin{array}{l}45-59 \\
\text { yrs }\end{array}$ & $\begin{array}{l}60+ \\
\text { yrs }\end{array}$ \\
\hline \multirow{3}{*}{$\begin{array}{l}\text { He/she believes in super- } \\
\text { natural powers }\end{array}$} & Always & 11 & 9 & 17 & 12 & 7 \\
\hline & Sometimes & 21 & 32 & 19 & 25 & 21 \\
\hline & Never & 68 & 59 & 64 & 63 & 72 \\
\hline \multirow{3}{*}{$\begin{array}{l}\text { Faith in God is for the } \\
\text { respondent }\end{array}$} & Very important & 10 & 6 & 10 & 13 & 10 \\
\hline & Partly important & 15 & 19 & 18 & 21 & 21 \\
\hline & Unimportant & 75 & 75 & 72 & 66 & 69 \\
\hline \multirow{4}{*}{ Religion is the salvation of } & I agree & 7 & 5 & 7 & 10 & 5 \\
\hline & I agree partly & 10 & 9 & 11 & 10 & 10 \\
\hline & I do not agree & 70 & 67 & 69 & 65 & 76 \\
\hline & I do not know & 13 & 19 & 13 & 15 & 9 \\
\hline
\end{tabular}

Source: Research titled The Influence of the Scope of Human Values.

Respondents spoke about the three aspects of religious orientation - belief in God, the importance of religion for humanity, and, in general, the recognition of supernatural powers. Belief in

27 For illustration, the representation of each age group was as follows: $15-29$ years covered $22 \%$ and the remaining three age groups covered 26\%. Far more uneven distributions of subsets are commonly used by foreign authors for publishing purposes. For example, Hunsberger, Pratt and Pancer in their article called Religious Versus Nonreligious Socialisation: Does Religious Background Have Implication for Adjustment?, The International Journal for the Psychology of Religion 2/2001, pp. 105-128. The article analyses the set of $\mathrm{N}=615$ with the following membership of the church respondents $28 \%, 8 \%, 52 \%, 12 \%$. 
supernatural powers is the most widespread. It is perceived by virtually a third of the population. At least approximately two-fifths of those under the age of 29 sometimes believe in it, but (on the other hand) only just over a quarter of those aged 60 and older do so. The situation is different in terms of belief in God. The smallest number of consistent and most reluctant answers is amongst the young generation. For some, it may be surprising that older middle-aged people represent the age group with the greatest importance of belief in God and at the same time with the least disagreement. A third of 45-59 year-olds gives greater or lesser importance to faith in God.

The expression of relationship to institutionalised forms of religion is the answer to the question about the role of religion in the salvation of mankind. The least agreeing and most disagreeing answers are expressed by members of the oldest generation of 60 and older. In this age group, the most likely influence is pre-November 1989 antireligious propaganda. However, the closest age group of 45-59 years old respondents expressed the most support for religion (one tenth) and the least disagreements (less than two-thirds). After 1989, this group formed a significant part of the emerging young generation, and its attitudes were formed on the basis of religious freedom (i.e., not only under the influence of antireligious activities of the previous regime).

A complementary view of religious attitudes provides answers to the question about the essence of the world, listed in Table 2.

Table 2: Opinions on the essence of the world given by the population of the Czech Republic and its basic age groups (in \%)

\begin{tabular}{|llllll|}
\hline The world has as its essence & CR & 15-29yrs & $\begin{array}{l}30-44 \\
\text { yrs }\end{array}$ & $\begin{array}{l}45-59 \\
\text { yrs }\end{array}$ & $\begin{array}{l}60+ \\
\text { yrs }\end{array}$ \\
Materialistic & 56 & 45 & 59 & 57 & 61 \\
Spiritual (governed by God) & 6 & 5 & 6 & 10 & 4 \\
The world has a different nature & 3 & 5 & 5 & 2 & 2 \\
I don't know / no answer & 35 & 45 & 30 & 31 & 33 \\
\hline
\end{tabular}

Source: The Influence of the scope of Human Values (specific research).

The materialistic view of the world prevails in the Czech population with more than half of the share. However, there are differences between age groups. Differences by age in previous responses are also confirmed by the given findings. Older middle-aged people most often hold religious ideas. The youngest respondents under the age of 29 are the least accustomed to the materialistic nature of the world, and most often they have failed to find some direction. A declared materialistic or religious view of the essence of the world does not always mean a clear view. More detailed analyses illustrate that a materialistic view of the world and, at the same time, the insignificance of faith in God holds for $44 \%$ of the respondents. The importance of faith in God and the spiritual nature of the world were given by $5 \%$ of respondents. The remaining $51 \%$ is characterised by a larger or smaller pairing of both positions.

The time comparison of faith in God within the main age groups has not yet appeared in the domestic literature. One can find research data about the relationship of the population towards religion, belief and the Bible obtained in 1991, where also belief in God was explored. The comparison of the 'I believe in God' response in 1991 and the great importance of faith in God in 2016 is given in Table 3. 
Table 3: Belief in God and the great importance of faith in God in age groups (1991 and 2016) in \%

\begin{tabular}{|llllll|}
\hline & CR & $15-29 y r s$ & $30-44 y r s$ & $45-59 y r s$ & $60+$ yrs \\
1991 & 25 & 14 & 20 & 27 & 43 \\
2016 & 10 & 6 & 10 & 13 & 10 \\
\hline
\end{tabular}

Source: The Influence of the Scope of Human Values (specific research) and About the Relationship of the Czech Population... (specific research). Counting is rounded to $100 \%$. In each field, there are other possible answers.

The data in the table can be evaluated from two points of view: a) to compare the differences between the age groups for each surveyed period, b) to analyse the answers in accordance with time and within the age groups.

Uniform differences of 6-7 percentage points were among the three age groups in the first survey, i.e., in 1991. Those were participants with a date of birth between 1932 and 1962. Most believers appeared in the group born in 1931 and earlier. There were 16 percentage points forming a distance from the previous generation and 29 percentage points was the distance from the youngest. The oldest were most often believers. The impact of religious education in this generation was stronger than the impact of antireligious propaganda.

Respondents from the second oldest age group formed the group of most believers in 2016, and they surpassed the oldest generation by number. However, the difference in the importance of faith between this and the youngest age group was only 7 percentage points. In the course of 25 years, a kind of religious 'homogenisation' took place in all age groups.

The second point of view reflects the reactions of the same generations in two different time periods. Differences between generational groups have been increasing over the period under review with increasing age. The representation of the faith of young people between 1991 and 2016 differs by 8 percentage points, and in the case of the oldest generations it is 33 percent. This means that the social circumstances of the last 25 years have been influencing each age group differently, with the biggest impact on the oldest generation.

The comparison of age groups for the years 1991 and 2016 offers an overview of the role of systemic circumstances in the formation of religious orientation, respectively the objective conditions of religious socialisation.

\section{The Course of Religious Socialisation}

The previous topic of the objective conditions of religious socialisation will be supplemented by the characteristics of the background for family religious socialisation. The assumptions of religious socialisation have been pursued in research through the testimony of the faith of each parent separately. The interpretation process will be the same as in the previous section, and we analyse responses across the population and subsequently in each age group. The data, in our opinion, indicates the conditions of primary religious socialisation for individual generations. 
Table 4: The statements of Czech citizens and people in basic age groups regarding the level of faith of their parents (in \%)

\begin{tabular}{|c|c|c|c|c|c|c|}
\hline & & CR & $15-29 y r s$ & $30-44 y r s$ & $\begin{array}{l}45- \\
59 y r s\end{array}$ & $60+$ yrs \\
\hline \multirow{3}{*}{ Mother is / was a believer } & Yes & 19 & 13 & 12 & 21 & 29 \\
\hline & Partly & 26 & 26 & 22 & 31 & 25 \\
\hline & No & 55 & 61 & 66 & 48 & 46 \\
\hline \multirow{3}{*}{ Father is / was a believer } & Yes & 11 & 8 & 10 & 13 & 14 \\
\hline & Partly & 17 & 18 & 15 & 16 & 18 \\
\hline & No & 72 & 74 & 75 & 71 & 68 \\
\hline \multirow{3}{*}{$\begin{array}{l}\text { Both parents are / were } \\
\text { believers }\end{array}$} & Yes & 7,3 & 5,5 & 4,4 & 9,2 & 10,3 \\
\hline & Partly & 38,7 & 44 & 35 & 47,3 & 47 \\
\hline & No & 54 & 50,5 & 60,6 & 43,5 & 42,7 \\
\hline
\end{tabular}

Source: The Influence of the Scope of Human Values (specific research).

Virtually every one fifth of our respondents has or had a genuinely religious mother. More than half of mothers are non-believing in the Czech Republic. The younger middle-aged generation gives a picture about, relatively speaking, the smallest number of mothers believing and (at the same time) the highest number of non-believing mothers is stated. The number of believing mothers in other age groups is on the rise and the proportion of non-believing mothers is decreasing. It is only natural that the most significant number of believers and the lowest share of unbelieving mothers is within the circle of the oldest generation. The 'special' part consists of the mothers of the youngest respondents. When compared to the nearest age group, the share of believing mothers is higher by 1 percentage point, and (at the same time) the representation of non-believing mothers is lower by 5 percent. Although these are not statistically significant differences with respect to sample size, the data may signal changes that occur in the perception of faith and religion even in parenting generations.

The share of believing fathers is generally lower than that of believing mothers. Every ninth father belongs to the circle of believers and almost three quarters to the non-believers category. The representation of the faithful fathers increases with the increasing age of the respondents, but not significantly (a total of 6 percentage points). The largest number of unbelieving fathers occurs in the age group of 30-44 years (three quarters). Older generations have fewer. The representation of non-believing fathers is 1 percentage point lower for young people under the age of 29 in comparison with the following age cohort. A slight difference may suggest a change in the current trend concerning the attitude towards the spiritual dimension of human life in the environment of the older middle generation of parents. Differences in the importance of the respondent's faith and the belief of mother and father illustrate a greater closeness to fathers' belief than to mothers' belief.

Looking more closely at the identity of the faith of both parents, it is clear that religiously oriented families in the Czech Republic are 7\%, non-religious oriented form more than half (54\%), and at least partly religiously oriented form almost two fifths (39\%). It is possible to repeat that the least religious (4\%) and most non-religious (61\%) are parents of the younger middle generation (30-44 year-old people). Those who are 60 and over themselves had mothers and fathers with the most religious orientation. 
It is reaffirmed that among the parents of the youngest respondents there is 1 percentage point more believers than in the group of parents in the next age group and, at the same time, by 10 percentage points less than the non-believers.

There is one other comparison, being that of parents' beliefs in 1991 and 2016 with the great importance of belief in God given by the respondents themselves. The following table compares the belief of the respondent and his or her mother in the age groups in the given years.

Table 5: Mothers and their faith in God in 1991, 2016 and the great importance of faith in God for the Participants 2016 (in \%)

\begin{tabular}{|lllll|}
\hline & $15-29 y r s$ & $30-44 y r s$ & $45-59 y r s$ & $60+$ yrs \\
Believin mothers 1991 & 23 & 42 & 55 & 69 \\
Believing mothers 2016 & 13 & 12 & 21 & 29 \\
Believing participants 2016 & 6 & 10 & 13 & 10 \\
\hline
\end{tabular}

Source: The Influence of the Scope of Human Values (specific research) and About the Relationship of the Czech Population... (specific research). ${ }^{28}$ Counting up to $100 \%$ in each field is represented by other answers.

Differences between the faith of the respondents and their mothers in each age group, as well as the differences in mothers' beliefs after 25 years, are indicated in the table. Today's young generation is different from its mothers by 7 percentage points, the younger middle generation by 2 percent, the older middle generation by 8 percent, and the oldest by 19 percentage points. The differences between the 60 year-old and older respondents and their mothers are the most striking. A gradual increase in the differences was noted in the survey of the share of believing mothers in generations today and 25 years ago. The smallest inequalities are in the younger generation (by 10 percentage points) and the most significant among the oldest (by 40 percentage points).

Changes concerning the respondent's and his/her father's faith are mentioned analogously. The data is presented in Table 5.

Table 6: Fathers and their faith in God in 1991, 2016 and the great importance of faith in God for the participants 2016 (in \%)

\begin{tabular}{|lllll|}
\hline & $15-29 y r s$ & $30-44 y r s$ & $45-59 y r s$ & $60+$ yrs \\
Believing fathers1991 & 17 & 23 & 34 & 54 \\
Believing fathers 2016 & 8 & 10 & 13 & 14 \\
Believing participants 2016 & 6 & 10 & 13 & 10 \\
\hline
\end{tabular}

Source: The Influence of the Scope of Human Values (specific research) and About the Relationship of the Czech Population... (specific research). Counting up to $100 \%$ in each field is represented by the other answers.

The beliefs of today's respondents show fewer differences towards their fathers' beliefs than towards the mothers' beliefs. The difference of 2 percentage points is in the youngest age group, the other two age cohorts are the same, and in the oldest age group the difference is 4 percentage points.

Differences between the years 1991 and 2016 (namely between the age groups), however, with the increasing age of respondents, are increasing. In the youngest generations, the fathers' belief dec-

28 Cf. Ján MIŠOVIČ et al., O vztahu čs. populace k náboženství a k Bibli, Praha: IVVM, 1991, p. 9; Ján MIŠOVIČ, Víra v dějinách zemí Koruny české, Praha: Sociologické nakladatelství, 2001, p. 130. 
lined by 9 percentage points over the 25 years. On the other hand, in the generation of 60 -year-old and older participants, the fathers' belief declined by 40 percentage points.

To illustrate the differences found, we present the results of the factor analysis with the six already used variables. We use Principal component analysis (PCA). The results are given in Table 7.

Table 7: The importance of individual factors in the religious understanding of the world

\begin{tabular}{|c|c|c|c|c|c|}
\hline Examined items & Extraction & Components & Total & $\%$ Variation & Kumulativ \% \\
\hline $\begin{array}{l}\text { 1. How important is belief in } \\
\text { God }\end{array}$ & .694 & 1. & 2.26 & 42.61 & 42.61 \\
\hline 2. Father was / is a believer & .690 & 2. & 1.06 & 17.70 & 60.31 \\
\hline $\begin{array}{l}\text { 3. Religion is the salvation of } \\
\text { mankind }\end{array}$ & .652 & 3. & .98 & 16.27 & 75.58 \\
\hline 4. Mother was / is a believer & .631 & 4. & .55 & 9.20 & 85.78 \\
\hline $\begin{array}{l}\text { 5. I believe in supernatural } \\
\text { powers }\end{array}$ & .467 & 5. & .44 & 7.40 & 93.18 \\
\hline $\begin{array}{l}6 \text { Has / does not have a world- } \\
\text { view }\end{array}$ & .484 & 6. & .41 & 6.82 & 100.00 \\
\hline
\end{tabular}

Source: The Influence of the Scope of Human Values (specific research).

The two strongest components (explaining a total of $60 \%$ dispersal of the six variables) proved to be the most important. The two variables are the importance of the respondent's faith and his or her father's belief.

The latest data will refer to religious transmission between parents and children in the form of religious and non-religious reproduction, deconversion, and conversion in each age group.

Table 8: The relation of the parents' faith and respondents' beliefs according to their age groups (\%)

\begin{tabular}{|lllll|}
\hline & $\begin{array}{l}\text { Reproduction of } \\
\text { faith }\end{array}$ & $\begin{array}{l}\text { Reproduction of } \\
\text { unbelief }\end{array}$ & Deconversion & Conversion \\
CR & 24 & 45 & 25 & 6 \\
$15-29 \mathrm{yrs}$ & 21 & 53 & 22 & 4 \\
$30-44 \mathrm{yrs}$ & 20 & 51 & 20 & 9 \\
$45-59 \mathrm{yrs}$ & 27 & 37 & 29 & 7 \\
$60+\mathrm{yrs}$ & 28 & 41 & 29 & 2 \\
\hline
\end{tabular}

Source: The Influence of the Scope of Human Values (specific research).

Those more or less accepting the faith of both their parents make up a quarter of the population in the Czech Republic. More than two fifths do not believe in the same way as their parents, one quarter of respondents separate themselves from the religious belief of their parents, and $6 \%$ of 
today's people (at least partially believing in God) were brought up by non-believing parents. ${ }^{29}$ Trends that emerged in the previous findings were also reflected in the table above. The reproduction of faith takes place in the two younger age groups giving the result of one fifth of respondents. We see transmissions for more than a quarter of respondents in the two older age groups. The difference between the age groups with the lowest and highest reproduction rates is 8 percentage points.

The reproduction of disbelief is most striking in the age group of 15-29 years, covering more than one half of this part. Similarly, it is also in the category of the younger middle generation. The reproduction of disbelief is least among the older middle generation (less than two-fifths).

The proportion of deconverted people is lower in younger age groups (around one fifth) and higher in the elderly (approaching one third). Lužný demonstrates this process on the results of qualitative research in Česká Lípa and Mikulov. Although a large number of people from the highly religious Slovak regions moved to Česká Lípa, these people did not engage in local religious life. On the contrary, young people from Mikulov lose their original religious interest after leaving their home to gain education, work. In the new environment, they were not interested in religious life. There may be a trend that Lužný calls the lack of interest and indifference, a condition that is 'perhaps even more cautious than if negative attitudes to traditional religion prevailed'. ${ }^{30}$

Religious conversion is very uneven. The lowest is among those 60 and older. The second lowest share of converts is recorded among the youngest. The most converts are among the younger generation of aged 30-44, with almost a tenth of them (9\%). In the older middle generation, conversion occurs more often than in the oldest and youngest age group.

\section{Reflection on the Results}

The Czech Republic is still considered to be one of the most secularised countries. This is documented by a number of sets of empirical data. ${ }^{31}$ Giving the religious manifestations examined, faith in supernatural powers takes the most obvious position. Virtually one third of the population recognises their impact. Younger age groups - more so than older - believe in these powers more often than in God. This is more than two fifths in the circle of young people, ${ }^{32}$ and in the younger middle generation of up to 44 years it is more than a third. The older middle generation, which had belonged to the youth group in the 1990s, represents the largest part of those for whom faith in God is either partly or very important and, also, this generation most often appreciates the role of religion for humanity. The oldest respondents, including those born in 1956 and earlier, represent a generation which sees all the aspects of religion examined as the least important. Their attitudes are closer to younger generations.

The acquired knowledge about generations corresponds in some way to the findings from the qualitative research of religious life in Hlučínsko. 'Some of the first generation think that while

29 According to the Czech Republic data from the ISSP 2008 research and another calculation method, intergenerational deconversion rates received 16 percentage points, conversion recieved 1 percentage point, intragenerational deconversion recieved 11 percentage points, and conversion recieved 1 percentage point. Cf. Antonín PALEČEK, Sekularizace z pohledu inter a intragenerační transmise: ČR ve srovnání postkomunistických zemí stř̌ední Evropy, Naše společnost 2/2015, pp. 13-26.

30 Cf. LUŽNÝ - NEŠPOR et al., Náboženství..., pp. 198-199.

31 This is also apparent from the ISSP 2008 data analysis. During the comparison of the regression coefficient (which reflects the influence of parents' attendance at worship on the religious beliefs of respondents from 38 countries) Turkey, with a value of 0.0005 was at the first place, and the Czech Republic, with a coefficient of 0.009, was in last place. The same state one can find during the comparison of the average religious belief (the first is Turkey with 0.95, and the last CR with 0.32). Cf. KELLEY, National Context..., pp. 295-314.

32 Not only according to the obtained data, but also according to Hamplova's knowledge, younger people tend towards 'alternative' religiosity. Cf. Dana HAMPLOVÁ, Čemu Češi věŕí: dimenze soudobé české religiozity, Sociologický časopis 4/2008, pp. 703-724. 
their children (second generation) do not go to church and do not practice their faith, their grandchildren, the third generation, are returning to faith. ${ }^{33}$

The temporal comparison of the faith of the respondents and the beliefs of parents over the last 25 years has enabled us to monitor the extent to which today's religious orientation has been influenced by the pre-1989 regime and (on the other hand) by the situation associated with the renewal of capitalism and democracy. Comparing the same generational groups 25 years ago and today suggests that the category of the oldest experienced the greatest decline in the importance of faith in God (by 33 percentage points). In 1991, the difference between the two age groups furthest apart was 29 percentage points, and now it is 7 percentage points. The boundaries of the importance of belief (in the understanding of various age groups) are being wiped out over the period under consideration, and the age cohorts are homogenised in this respect. Due to the generational exchange, the proportion of believers amongst the elders has reached the same point as the number of believers in other age groups. One significant change has occurred over the past years: the oldest respondents today are not the most religious, and this position has been taken over by the older middle-aged generation up to 59 years of age.

The parents' belief offers a complementary look at the generational background of the respondents. The share of completely and partly believing parents in the age range from young to older middle generations is rising from $47 \%$ to $63 \%$. In the range of 60 year-old and older people, this is $59 \%$. This fact has had a different effect on religious orientation, as illustrated by previous results. In the youngest age group, the most prolific reproduction of unbelief occurs. The younger middle generation converts the most often. In the environment of the older middle generation, disbelief is reproduced the least, but the proportion of deconverts is higher than in younger age groups. Among the oldest respondents, faith was most often reproduced, but conversions are the least frequent.

The results obtained from today's point of view probably do not agree with Nešpor and his opinion. According to that, (in Czech society as a whole) the communist struggle against religion between 1948-89 ended successfully, by de-Churching society. ${ }^{34}$ It is certainly possible to speak about such a success when looking at today's generation of 60-year-olds and older, but the other major part of the population is only partially influenced by the anti-religious activities before 1989, or is not influenced at all. The data even suggests that the last generation who experienced a 'campaign against religion' turned to faith in the supernatural rather than to the ecclesial religion, as did the young generation born after 1987. The logic of this comparison suggests that even the present social system is de-Churching society, even if it does not manifest itself through direct anti-religious elements. On the basis of the above findings, it is possible to answer the research question: in the process of religious socialisation, parental religious socialisation is primary, but other factors (represented by the wider environment and the whole society) have played in the past decades and still play a decisive role in contemporary social conditions.

33 In relation to the three generations characteristic, there is no age. We can find there only education, professional classification and marital status. Yet, it can be assumed that (in our classification) we are talking about the elderly middle generation, the younger middle, and the youngest generation. Cf. Helena KUBÁTOVÁ et al., Mezigenerační proměny zpưsobu života na Hlučínsku, Praha: Sociologické nakladatelství, 2015.

34 Cf., for example, Zdeněk R. NEŠPOR, Př́liš slabí ve víře, Praha: Kalich, 2010. 


\section{Conclusion}

In Czech society, the same mechanisms of religious socialisation apply as in other parts of Europe. Writers dealing with the religious situation in the world have noticed that there are no differences in terms of religious exclusiveness today. This comes from the fact that the long-running effort of communist systems to fight religion could have affected people's faith only for a few years after the fall of the regime. ${ }^{35}$ After 1990, life in the Czech Republic has verified well the fact that the transmission of religious beliefs outside the family depends to a large extent on the social context. ${ }^{36}$ The hypothesis saying that social and economic conditions have more significant influence on the religious socialisation of offspring than parenting has been confirmed in this respect. A trend that began in Northern and Western Europe in the 1950s, coupled with the steadily fading influence of Christian tradition and the growth of post-traditional spirituality in recent decades ${ }^{37}$ is also manifesting itself in the Czech Republic as a consequence of the existing social situation.

Experts wonder why religious education is (in most cases) less effective. The answers are found in the analysis of the interaction between subjective and objective conditions. The view of parental religious education points to several typical general features: a) parental influence is indirect, ${ }^{38}$ b) religious socialisation is directed towards reproduction rather than towards the increase of religiosity, and c) there are no differences in the influence of parents on children in religiously oriented and secularised countries. ${ }^{39}$ It is possible that the long-term effect of religious education directed at young people is weakened by socio-cultural development at the macro level ${ }^{40}$ Added to this is the fact that the psychological need to turn to religion in a situation of improving living conditions is decreasing and the role of religious socialisation within the family becomes more demanding. ${ }^{41}$ Young people are less religious than older people, both in the Czech Republic and in the world. It is a reflection of historical changes linked to a higher level of human development rather than to something that links with the cycle of human life. ${ }^{42} \mathrm{~A}$ full understanding of the religious socialisation process requires attention to both levels, the micro and macro levels, and their interaction. The socialisation process cannot be studied independently of the social context. Religious and non-religious socialisation involves both parental religious socialisation and other factors including the wider environment and society in the past and today.

35 Cf., for example, KELLEY, National Context..., pp. 295-314.

36 Cf., for example, MÜLLER - SCHMIDT - DE GRAFF, Which Societies..., pp. 739-759.

37 Cf., for example, Dick HOUTMAN - Stef AUPERS, The Spiritual turn and the decline of tradition: the spread of Post-Christian spirituality of fourteen Western countries, Journal for the Scientific Study of Religion 3/ 2007, pp. 305-320.

38 Cf., for example, Kent JENNINGS - Laura STOCKER - Jake BOWERS, Politics Across Generations: Family Transmission Reexamined, The Journal of Politics 3/2009, pp. 782-799.

39 Cf., for example, STORM - VOAS, The Intergenerational..., pp. 131-150.

40 Cf., for example, Paul VERMEER - Peer SCHEEPERS, Religious Socialisation and Non-Religious Volunteering: A Dutch Panel Study, Voluntas 23/2012, pp. 940-958.

41 Cf., for example, MÜLLER - SCHMIDT - DE GRAFF, Which Societies..., pp. 739-759.

42 Cf., for example, Pippa NORRIS - Ronald INGLEHART, Sacred and Secular: Religion and Politics Worldwide, New York: Cambridge University Press, 2004. 


\title{
Differences in Religious Socialisation across Generations
}

\begin{abstract}
Religious socialisation has been an important issue for many foreign authors. In their analysis, they use (in addition to domestic research data) data containing information about national units which are obtained from the International Social Survey Program (ISSP) 2008: Religion III. The topic of religious socialisation is beginning to attract attention even within Czech professional discourse. The article builds on existing approaches and focuses on the circumstances of religious socialisation in the Czech Republic. It deals with the degree of intergenerational transmission of religious ideas. The aim is to evaluate the form of religious worldview within the main age groups of the Czech population and their parents. During the interpretation of the findings, the results of a representative survey (carried out from December 2015 to January 2016 among the population of the Czech Republic aged 15 and older in the range of 522 respondents) were used. The data obtained enabled a comparison of the shifts in faith in God since 1991.
\end{abstract}

Keywords: religious socialisation, personal faith, the faith of parents, generations, spirituality.

\section{Author contact}

Dr. Ján Mišovič

University of South Bohemia, České Budějovice

Faculty of Theology, Department of Ethics, Psychology and Charity

Kněžská 8, 37001 České Budějovice

Email: misovic@tf.jcu.cz 